\title{
Between Tourism and Ecology : Review of Political Policy Commitments on Ecotourism Development in Bangka Belitung
}

\author{
Ibrahim Ibrahim ${ }^{1 *}$, Nizwan Zukhri ${ }^{2}$, and Rendy Rendy ${ }^{3}$ \\ ${ }^{1}$ Department of Political Science, Faculty of Social and Political Sciences, Universitas Bangka Belitung, Bangka - Indonesia \\ ${ }^{2}$ Department of of Management, Faculty of Economic, Universitas Bangka Belitung, Bangka - Indonesia \\ ${ }^{3}$ Department of Political Science, Faculty of Social and Political Sciences, Universitas Bangka Belitung, Bangka - Indonesia
}

\begin{abstract}
Tourism and ecology are two important issues in regional development planning in Bangka Belitung. As an archipelago that has a productive tin mining area, environmental damage is an important issue. Not only because of the impact of damages due to mining, but the dimensions of tourism which are important sectors in this area are also affected. In recent years, local governments in the Bangka Belitung region are focusing on working on the issue of tourism by relying on the ecotourism sector as an important alternative to post-mining. This study explores how political policies are arranged in regional planning documents. The research method used was descriptive qualitative by examining the regional medium-term development planning documents in 6 districts, 1 city, and 1 provincial government in Bangka Belitung. This study found 4 things. First, that none of the regional governments listed the vision of tourism and only 1 region that included an ecological vision. Secondly, the study found that there was only one government that made the issue of tourism in the development mission and only 3 regions mentioned the ecological mission, the rest only mentioned implicitly. Third, each region places tourism and ecological issues as two different programs, not considered an issue that must be managed synergistically. Fourth, almost all regional planning documents mention tourism and ecology as regional strategic issues, but they are not balanced with a strong vision, mission, and work program as a translation. Fifth, only 4 out of 8 regions have made the issue of developing ecotourism a regional strategic issue even though it has not been followed by a strong design development in development planning. In the end, this study concluded that tourism and ecology had not been placed optimally in planning documents politically.
\end{abstract}

\section{Introduction}

As a tin mining area, the Bangka Belitung Islands are faced with the threat of environmental damage. Since hundreds of years this area has been mined, environmental damage is a fundamental problem $[1,2,3$, $4,5,6]$. Although known as a beautiful area with a long coastline, the next problem is whether it is possible to package tourism and mining interests in one context at a time. At present, along with the decreasing tin reserves and declining tin mining activities, the local government is designing a post-mining economic alternative, namely tourism development.

The Bangka Belitung Islands, located in the South of Sumatra Island and in the form of islands, have seven regions divided into 6 districts and 1 city. Local governments in each region are designing a tourism development design that is expected to bring new sources of income post-mining [7]. Although mining is still the choice for the second profession after the plantation sector [8], mining activities are indeed designed to be abandoned [9].

In each campaign, every regional head, from governor to regent or mayor, always makes the post-mining era and preparations for tourism vision as one of the campaign materials. Tourism development was used as a campaign because it was considered to be one of the needs for new income after the tin mine was no longer popular.

In fact, almost all regions today are indeed developing the image of tourism development. This is at least reflected in all Regional Medium Term Development Plan (RPJMD) documents that are valid for 5 years in accordance with the regional leadership leader $[10,11,12$, $13,14,15,16,17]$. On various occasions, politically the elected regional heads will make this program a superior one. In the end, campaign promises will be part of the vision and mission documents that must be included in the regional mid-term development plan (RPJMD) prepared immediately after the elected regional head. This document will be an official document for 5 years and will become an official state document.

The study raises the main question: how do regional heads place tourism, ecological and ecotourism issues in political policy design on planning documents?

\section{Research Methodology}

\footnotetext{
* Corresponding author: iim_babel@yahoo.com
} 
This study uses descriptive qualitative research methods to describe how political planning design in ecotourism development. The object studied is a regional midterm development plan document prepared after the regional head is in office and used as a guideline in the development for five years of political leadership of a regional head. The locus is all districts and cities, namely Bangka, Bangka Tengah, Bangka Barat, Bangka Selatan, Pangkal Pinang, Belitung, East Belitung, and the Provincial Government of Bangka Belitung. Data collection techniques are documentation, namely by reviewing documents and comparing between planning documents of each region.

\section{Finding and Discussion}

Tourism and ecology are two entities that form the context of ecotourism. Eco tourism itself is understood as a form of tourism that is responsible for the preservation of unspoiled areas, provides economic benefits and maintains cultural integrity for the community, and is very closely related to the principle of conservation $[18,19,20$, $21,22]$. This study will start from the mapping of vision, mission, programs, and ecotourism opportunities in regional development planning documents.

\subsection{Vision Commitments}

Commitment to the vision of ecotourism leadership in general is not explicitly stated in almost all planning documents contained in the 8 documents reviewed. The author finds that ecotourism entities are still placed and managed differently between tourism and ecological development separately.

The following is table 8 of the intended vision:

Table 1. Vision of Regional Development

\begin{tabular}{|l|l|}
\hline $\begin{array}{l}\text { Provincial } \\
\text { government }\end{array}$ & $\begin{array}{l}\text { Prosperous Babel, Advanced } \\
\text { Province }, \quad \text { Superior in } \\
\text { Agropolitan and Maritime } \\
\text { Innovation with Efficient and } \\
\text { Fast Technology-Based Public } \\
\text { Governance and Servicesi }\end{array}$ \\
\hline Bangka & $\begin{array}{l}\text { Bangka (SETARA) Prosperous } \\
\text { and Noble }\end{array}$ \\
\hline South Bangka & $\begin{array}{l}\text { The realization of South Bangka } \\
\text { to become an independent, } \\
\text { advanced, prosperous and } \\
\text { competitive }\end{array}$ \\
\hline Central Bangka & $\begin{array}{l}\text { Central Bangka is prosperous, } \\
\text { based on community economy, } \\
\text { and sustainable }\end{array}$ \\
\hline South Bangka & $\begin{array}{l}\text { Realization of Independent, } \\
\text { Advanced, Prosperous and } \\
\text { Competitive South Bangka }\end{array}$ \\
\hline West Bangka & $\begin{array}{l}\text { Heading to Great Bangka Barat } \\
\text { Regency 202 }\end{array}$ \\
\hline Pangkal Pinang & $\begin{array}{l}\text { Realizing Pangkal Pinang as a } \\
\text { 'SENYUM' City (Prosperous and } \\
\text { Comfortable Superior) }\end{array}$ \\
\hline
\end{tabular}

\begin{tabular}{|l|l|}
\hline Belitung & $\begin{array}{l}\text { Realizing an equitable, } \\
\text { competitive and innovative } \\
\text { economy in Belitung Regency in } \\
2023\end{array}$ \\
\hline East Belitung & $\begin{array}{l}\text { Advanced and superior East } \\
\text { Belitung based on local resources }\end{array}$ \\
\hline
\end{tabular}

If we look at the Vision statement above, it can be concluded that there are two variations of the commitment, namely: explicitly mentioning the description of the vision and not mentioning it, both tourism and ecological. This is illustrated in the following table :

Table 2. Issue Issues

\begin{tabular}{|l|l|}
\hline $\begin{array}{l}\text { Mentioning } \\
\text { ecological issues }\end{array}$ & No Mentioning \\
\hline • Central Bangka & - Provincial government \\
& - South Bangka \\
& - Belitung \\
& - East Belitung \\
& - Pangkal Pinang \\
& - South Bangka \\
& - West Bangka \\
\hline
\end{tabular}

The table above shows that none of the regions mentioned tourism development as part of the regional development vision. Only Central Bangka explicitly mentions the ecological dimension in the vision of development.

\subsection{Mission Commitments}

Commitments to ecotourism development as stated in the regional head's mission in the planning documents are varied. The author identifies several variations, namely (1) mentioning tourism as one of the missions, (2) mentioning tourism as an alternative, (3) mentioning it as an ecological mission, and (4) not mentioning.

The following is a table of mission commitments in question:

Table 3. Development Mission

\begin{tabular}{|c|c|c|c|}
\hline $\begin{array}{l}\text { Tourism } \\
\text { Mission }\end{array}$ & $\begin{array}{l}\text { Tourism as } \\
\text { an } \\
\text { alternative } \\
\text { in Mission }\end{array}$ & $\begin{array}{l}\text { Ecologic } \\
\text { al } \\
\text { mission }\end{array}$ & $\begin{array}{l}\text { No } \\
\text { mission } \\
\text { mentioned }\end{array}$ \\
\hline - Bangka & $\begin{array}{l}\text { - Provincial } \\
\text { governme } \\
\text { nt } \\
\text { - Pangkal } \\
\text { Pinang } \\
\text { - West } \\
\text { Bangka }\end{array}$ & $\begin{array}{l}\text { - West } \\
\text { Bangka } \\
\text { - Belitun } \\
\text { g } \\
\text { - } \text { Central } \\
\text { Bangka }\end{array}$ & $\begin{array}{l}\text { - South } \\
\text { Bangka } \\
\text { - East } \\
\text { Belitung }\end{array}$ \\
\hline
\end{tabular}

The table above shows that tourism is placed a little as a mission, while more mention tourism as an alternative option. As for the relatively many ecological missions listed, however, many regions also do not mention it at all in planning documents, both tourism development and the development of ecological missions. 


\subsection{Program Commitments}

Commitment to the development of ecology and tourism as part of local government work programs is raised in relatively diverse variations in planning documents. The author identifies at least two forms of commitment, namely: ecotourism programs and ecological programs which according to the authors relate to efforts to create ecotourism development. The variety and number of programs described in the following table:

Table 4. Number of Programs

\begin{tabular}{|l|c|c|}
\hline Area & $\begin{array}{l}\text { Tourism } \\
\text { program }\end{array}$ & $\begin{array}{l}\text { Ecological } \\
\text { program }\end{array}$ \\
\hline $\begin{array}{l}\text { Provincial } \\
\text { government }\end{array}$ & 2 & 1 \\
\hline Bangka & 6 & 4 \\
\hline South Bangka & 2 & 4 \\
\hline Central Bangka & 3 & 6 \\
\hline West Bangka & 3 & 7 \\
\hline Pangkal Pinang & 1 & 8 \\
\hline Belitung & 5 & 4 \\
\hline East Belitung & 3 & 6 \\
\hline
\end{tabular}

Based on the table above, it can be found that Bangka and Belitung districts place the most tourism development in their regional government work programs, while the most commitment to ecological development is Pangkal Pinang and West Bangka. If examined in terms of the number of work programs for tourism and ecological development, then Bangka and West Bangka are the two regions that have the most planned tourism and ecological development. While the least in planning is the provincial government.

\subsection{Ecotourism and 'Half-Heart' Commitment}

It is interesting to look at all regional planning documents in the Bangka Belitung Islands Province. All regions include tourism issues as part of strategic issues. Strategic issues are issues that are considered to have an impact on the region and then are reduced in the form of vision, mission, policy direction and work program.

Bangka Regency puts the issue of tourism as a strategic issue and the development of tourism spots as one of the targets in the development plan. In addition, another goal is to improve the quality of the environment. Meanwhile East Belitung makes tourism one of the directions of policy, while one of the strategic issues is the development of tourism and industry. Low environmental carrying capacity is also one of the strategic issues in planning this area.

South Bangka Regency also places a strategic issue on tourism and heritage, while ecosystems and conservation are also part of the strategic issues of this area. For Pangkal Pinang, the contribution of the tourism sector is also highlighted as one of the strategic issues besides the issue of pollution and waste management. Belitung, which has been known to be diligent in making the tourism sector an environmental issue, also puts the issue of developing the tourism sector as one of the important themes in development

In Central Bangka Regency itself, the weak ability to manage the tourism sector, especially natural potential as a mainstay, has not been done much. With this condition, Central Bangka includes the issue of tourism as one of the important issues in addition to environmental damage that must be managed. In a different place, West Bangka makes the problem of the not yet optimal coastal natural tourism sector with all its potential as an important issue, besides environmental damage that is considered fatal.

As for the provincial government itself, the tourism sector has not been optimally highlighted as an important issue, while the inconsistency of spatial planning and environmental degradation has become one of the important concerns in this government's strategic issues.

By looking at the findings above, it can be seen that basically tourism issues and ecological issues are two things that are considered important and are included as one of the strategic issues. Nevertheless, this study has found that there are inconsistencies between the issues on strategic issues with the vision, mission, and work programs that have been developed that have not supported each other. That is, strategic issues are not followed by programs that are taken seriously. If observed, in planning, Bangka Regency is the most serious area to place the issue of tourism development as something important in its mission, while the tendency in other regions is to only make tourism issues a sub-alternative even though all regions realize that tourism is an important issue.

Beyond that, ecological missions tend to be an important issue by some regions, at least Central Bangka, West Bangka and Belitung which make environmental issues part of their mission. The South Bangka and East Belitung do not make tourism issues or environmental issues a part of the mission mentioned explicitly.

There are only 3 regions that place the issue of eco tourism development as something important even though it is not mentioned in the regional vision, mission and work programs, namely Central Bangka, West Bangka, Bangka, and Belitung. Bangka Tengah believes that the development of tourism potential based on natural potential is not optimal, while Banka Barat thinks that their region is still focused on historical tourism and has not worked on the potential of coastal tourism areas. Bangka itself highlights the importance of building new tourism spots, while Belitung places the development of national strategic tourism areas in their area as important. However, from all the anxiety regarding the development of ecotourism-based tourism spots, it has not been reflected in the vision, mission, and work program that will be carried out during the five years of regional government running. These indicated that the tourism and environmental sectors were only considered important as the strategic issues; however, they have not been adequately described in a working program.

\section{Conclusion}


This study examines the commitment of local governments in the Bangka Belitung Islands Province with regard to tourism development, ecology, and finally on tourism development. This study found several things. First, that none of the regional governments listed the vision of tourism and only 1 region which included an ecological vision, namely Central Bangka Regency. Second, the study found that there was only one government that made the issue of tourism in the development mission and only 3 regions mentioned the ecological mission, the rest only mentioned implicitly. Only Bangka Regency made the issue of tourism an explicit mission and Bangka Barat, Belitung, and Central Bangka which made the environment an explicit mission. Third, each region placed tourism and ecological issues as two different programs. It was not considered as an issue that must be synergistically managed. Fourth, almost all regional planning documents mention tourism and ecology as regional strategic issues, but they are not balanced with a strong vision, mission, and work program as a translation. Bangka and Belitung make the tourism issue the most as a work program, while Pangkal Pinang and Bangka Barat make the most ecological issues as work programs. In general, Bangka is the region that has given the most attention to the portion of development for the two issues in question. Fifth, only 4 out of 8 regions have made the issue of developing ecotourism a regional strategic issue even though it has not been followed by a strong design development in development planning. In the end, this study concluded that tourism and ecology had not been placed optimally in planning documents politically.

Thanks to Directorate of Higher Education of Ministry of Research, Technology, and Higher Education for supporting this research by National Competitive Research Grant 2019-2021.

\section{References}

1. S. Sujitno, Impact of the Presence of Indonesian Tin throughout History, Cempaka Publishing, Jakarta (2015)

2. E. Erman, Jurnal Masyarakat Indonesia, Actors, Access and Environmental Politics in Bangka Tin Mining, Edisi XXVI, No. 2, pp. 71-101 (2010)

3. I. Ibrahim, et.al., PEOPLE : International Journal of Social Sciences, From Charm to Sorrow (The Dark Portrait of Tin Mining in Bangka Belitung, Indonesia), Volume 4, Issue 1, pp. 360-382 (2017)

4. K. Muslih, et.al., AKUATIK-Jurnal Sumber Daya Perairan, Karakteristik Habitat dan Keanekaragaman Ikan Air Tawar Sungai Menduk yang Mendapat Pengaruh Penambangan Timah di Kabupaten Bangka, Habitat Characteristics and Biodiversity of Freshwater Fish in Menduk River that Got Influence Tin Mining in Bangka, Volume 8, No. 2, pp. 17-23 (2014)

5. Susilo, Joko \& Siti Maemunah, Three centuries of Serving the World, Portrait of Tin Mining Bangka
Belitung, Mining Advocacy Network (JATAM), Jakarta (2009)

6. Ibrahim, D. Haryadi, N. Wayudin, Knowledge of the context, behavior, and expectations of miners in relation to the tin mining political policies and practices in Bangka Belitung, Journal of Society, Culture and Politics Vol. 31, Issue 4, pp. 358-367 (2018)

7. R.S. Wardhani, D. Valeriani, Green Tourism in Bangka Belitung Tourism Development, Today's Global Economic Scientific Journal, Vol. 7, No.1, pp. 24-29 (2016)

8. I. Ibrahim, et.al., Already dependent: a dependency analysis of market activity on tin mining in Bangka Belitung, E3S Web of Conferences, Vol. 91, pp.1-10 (2019)

9. D. Valeriani, Tourism Development Policy in the Bangka Belitung Islands Province, Journal Equity, Vol. 1, No. 4, pp. 1-27 (2010)

10. Regional Regulation No. 14 of 2017, the Medium Term Development Plan of the Province of the Bangka Belitung Islands in 2017-2022

11. Regional Regulation No. 12 of 2016 South Bangka Regency Medium Term Development Plan for 20162021

12. Final draft of the Bangka Regency Medium-Term Regional Development Plan for 2019-2023

13. Regional Regulation No. 11 of 2016 East Belitung Regency Middle Term Development Plan 2016-2021

14. Final draft of the Mid-Term Development Plan for the Belitung Regency Year 2018-2023

15. Preliminary Design of the Mid-Term Development Plan of the Belitung Regency Year 2018-2023

16. Regional Regulation No. 7 of 2016 West Bangka Regency Medium Term Development Plan for 20162021

17. Middle-term Regional Development Plan for Central Bangka Regency 2016-2021 1

18. C. Fandeli, Nature Tourism Planning, Fakultas Kehutanan UGM, Yogyakarta (2002)

19. J. Damanik, H.F. Weber, From Theory to Applications, Yogyakarta (2006)

20. D. Fannel, Ecoturism, York: Routledge. cf. Ecotourism in the South African context. Africa Insights 33(1): 1-8. (2003)

21. I. Nugroho, e.t.al, Promoting the Rural Development through the Ecotourism Activities in Indonesia, American Journal of Tourism Management, Vol. 5, No.1, pp. 9-18 (2016)

22. R. Butarbutar, Soemarno, Environmental Effects of Ecotourism in Indonesia, Journal of Indonesian Tourism and Development Studies, Vol. 1, No. 3, pp. 97-107 (2013) 